\title{
HONVÉDELEM
}

\section{Fórizs Sándor^}

\section{A határórség sorállománya 1956-1957-ben}

DOI 10.17047/HADTUD.2020.30.3.39

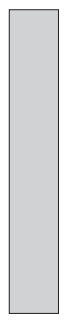

A tanulmány a magyar határőrségnél 1956-1957-ben szolgálatot teljesítô sorállomány helyzetét, a velük kapcsolatos eseményeket mutatja be a Magyar Nemzeti Levéltár Országos Levéltárában fellelhető dokumentumok alapján. Megismerteti a határórség sorállományának néhány jellemző tevékenységét az érintett időszakban, az államhatár lezárásának körülményeit, valamint a honvédségi katonák átcsoportosítását az államhatár ôrizetére az 1957-es évben. A szerzó elemzi a sorkatonai állomány szerepét az államhatár órizetének 1957. évi újjászervezésében.

KULCSSZAVAK: határôrség, határốr ôrs, járőrszolgálat, katonai szolgálat, külföldre szökés, Magyar Honvédség, országos parancsnokság, sorállomány

\section{The Conscripted Personnel of the Border Guard in 1956-1957}

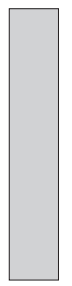

Based on the documents in the National Archives of Hungary, the paper presents the status of the conscripted personnel of the Border Guard having served in the years 1956-1957, and the events related to them. It discusses some of their typical activities at those times, the circumstances of closing the state border and the redeployment of soldiers of the Hungarian Army to guard the state border in 1957. The author also presents the role of the conscripted personnel in the reorganisation of the guarding of the state border in the year 1957.

KEYWORDS: Border Guard, border guard post, patrol service, military service, desertion to a foreign country, Hungarian Armed Forces, National Headquarters, conscripted personnel

\section{Bevezetés}

Magyarországon az 1950-es évben a kötelező sorkatonai szolgálat idejét három évre emelték, majd 1956-ban, még az októberi események elótt jelentették be annak csökkentését két év három hónapra. Sorállománnyal ebben az idóben még a Magyar Honvédség és a Belső Karhatalom rendelkezett. ${ }^{1}$

\footnotetext{
↔ Nemzeti Közszolgálati Egyetem - National University of Public Service; e-mail: forizs.sandor@uni-nke.hu; ORCID: 0000-0001-6019-3295

1 „Sorállomány: a fegyveres erókbe - a honvédséghez és a határórséghez - a törvényben rögzített sorkötelezettség alapján katonai szolgálatuk teljesítésére bevonult hadkötelesek állománycsoportja." Hadtudományi Lexikon M-ZS. Budapest, Magyar Hadtudományi Társaság, 1995. II. 1219. o.
} 
1956-1957-ben a határőrségnél meghatározó állománykategória volt a sorállomány. A határőrségi járôrrendszerú szolgálatellátás tekintetbe véve azt a központi követelményt, hogy legyen képes a jugoszláv és az osztrák államhatár hézagmentes lezárására, nagy létszámot és speciális szolgálati módra felkészített, jól kiképzett állományt igényelt.

A szervezet múködését mondhatjuk, a sorállomány biztosította. Ez nem csak a tényleges szolgálatellátást jelenti. A kiszolgáló apparátusban elenyészó számban dolgozott polgári személyzet. A javítás, a karbantartás, a nyilvántartás, a híradó biztosítás, az étkeztetés-fózés, a raktározás, a szállítás, úgyszólván minden a sorkatonák vállán nyugodott. Még az építkezésekben is meghatározó szerepet játszottak. Az 1956-os évben komoly szerepük volt az aknamezó (múszaki zár) felszedésében, illetve a jugoszláv államhatáron akkor folyó határfelmérési és határjel karbantartási munkálatokban.

Ezt a közel 300 szolgálati helyre széttagolt állományt teljesen váratlanul érték az októberi események, akárcsak az óket irányító tiszteket, és az jórészt felsóbb utasítások nélkül sodródott az állandóan változó, ellentmondásos viszonyok között. A történések folyamán, a távoli tanyai oórsökön, elvágva minden konkrét információtól, a legjobb esetben nem tettek semmit, várakoztak. Ezt követôen alkalmazkodniuk kellett a november 4-e után bekövetkezett fordulathoz, az államhatár ôrizetének megszigorításához.

Ugyanakkor az egyetlen országos szintú szervezeti vezetést, a határốrség parancsnokságát, amely az 1956-1957-es évek fordulója során vezetóváltás nélkül, Szalva János ezredes országos parancsnokkal az élén, a helyén maradt, komoly nehézségek elé állították a sorkatonák kezelésének kérdései. Az 1957. évi határórségi sorállomány kialakításában (a tiszti állomány esetében is) meghatározó szerepet játszott a Magyar Honvédség. Az országos parancsnokot is Gyurkó Lajos honvéd vezérốrnagy váltotta 1957 augusztusában. „A MT 3338/1957.Mt sz. határozatával Gyurkó Lajos vezérórnagyot kinevezte a Belügyminisztérium Határórség parancsnokává, egyben felmentette a HM kiképzési csoportfő́nöki beosztása alól."2

Publikációmban a határốrség sorállományának az 1956-1957-es években kialakult rendkívüli helyzetével kívánok foglakozni a Magyar Nemzeti Levéltár Országos Levéltárában fellelhetố dokumentumok alapján, amelyek az MNL HOP-B-10 számon, az érintett évek dobozaiban találhatóak.

\section{A sorállomány 1956-ban}

A határórség, mint a fegyveres erók része, jelentốs sorállománnyal rendelkezett. Az 1953-as létszámcsökkentéseket követôen, 1956. áprilisban rendszeresített sorlétszáma 12399 fố volt. Évente egyszer került sor bevonulásra, és a hároméves sorkatonai szolgálati idő miatt egyszerre három korosztály tevékenykedett a szervezetben:

- Az '53-as bevonulású korosztály ('53. nov. 10. bevonulás) 3970 fó.

- Az '54-es korosztály ('54. aug. 25.) 4394 fó.

- Az '55-ös korosztály ('55. aug. 16.) 3972 fó.

2 A határôrség országos parancsnokának 0053. sz. parancsa, aug. 12. MNL HOP XIX- B-10 1957. év. 1. sz. doboz I-1. tárgykör, 1. folyószám. Fontosabb határórizeti intézkedések gyújteménye, 1950-1957. 
Az eloóirt létszámból csupán 63 fó hiányzott. Évenként 6200, illetve 6199 újoncra volt szükség, természetesen a behívásokat rátartással tervezték. A határórséghez 8427 fó, a belső karhatalomhoz 3277 fó újoncot kívántak behívni ebben az évben. Ez a behívás a késóbbi események miatt elmaradt, viszont a novemberi leszerelést, esetenként megkésve ugyan, de végrehajtották. Ezzel jelentôs sorkatonai hiány alakult ki a november-december hónapokban. Az'53-ban bevonultakat három év szolgálat után november tizedikén kellett az eredeti terv szerint leszerelni. ${ }^{3}$ A helyzetet nehezítette, hogy 1957 februárjában is tartottak leszerelést, tovább csökkentve a tapasztalt katonák létszámát.

A parancsnokság úgy számolt, hogy az új rendszerre véglegesen az 1959-es évben tudnak átállni. A következő leszerelésre és bevonulásra 1956. 11. 10-én került volna sor, és azt az alapkiképzésnek 1957. 02. 10-ig kellett követnie, de mindezt a késóbbi események lehetetlenné tették. A határôrség az októberi-novemberi események során éppen a legidôsebb, legtapasztaltabb korosztályát volt kénytelen nélkülözni, akik a szolgálati idô leteltével vagy még azt megelőzó́en leszereltek, esetleg egyszerúen elhagyták a szolgálati helyüket.

A bevonulást két és fél hónapos alapkiképzés követte valamelyik kiképzôzászlóaljnál. A tiszteseknek kiválasztottak külön tisztesiskolára kerültek. Érdekes módon a határốrség ebben az idóben nem rendelkezett hivatásos tiszthelyettes állománnyal. Ezt a szolgálati kategóriát, szakmailag teljesen érthetetlen okokból 1950-ben, a szervezet ÁVH-hoz kerülését követốen, az ÁVH vezetóje 38. sz. parancsával (037/1951.ÁVH.T.Biz.sz.) 1951. 07. 01. hatállyal megszüntette, és helyette a „továbbszolgáló tiszthelyettesi állományt" rendszeresítették.

1956 augusztusában 847 továbbszolgáló beosztás szerepelt az állománytáblában. Maga a magas szám is mutatja, mennyire szükség lett volna erre az állománycsoportra, és nem a tiszteket terhelni mindenféle apró-cseprô ügy rendezésével. Még az ekkor gyakran másolt szovjet katonai rendszernek is ellentmondott ez a megoldás, hiszen a szovjet fegyveres erók komoly hivatásos állományú tiszthelyettesi gárdával rendelkeztek. Az 1950-es intézkedés talán azzal magyarázható, hogy politikai megfontolásokból kívántak megszabadulni tólük ezen az úton, mivel a határvadász tiszthelyettesek jelentôs része korábban a Horthy-hadseregben szolgált, és ekkor részben ók látták el az ôrsparancsnoki teendóket is.

Csak jóval késóbb, 1957. 05. 20-án tesz javaslatot a határórség a belügyminiszternek egy hivatásos tiszthelyettesi állomány rendszeresítésére. Az anyag hivatkozik a honvédelmi miniszter 1957. 04. 12-én kelt 9. sz. parancsára, amelyben elrendelte a hivatásos tiszthelyettesi állomány létesítését a honvédségnél, valamint arra, hogy az MNVK Fốnöke 13. számú intézkedésében meghirdette a hivatásos tiszthelyettes állományba történó jelentkezést. ${ }^{4}$

3 „Tárgy: A BM. Hốr., valamint a BM. BK. 1956. évi újoncigénylése.” 1956. 04. 24. MNL HOP XIX-B-10 1956. év 19. sz. doboz VII/4. tárgykör, 77. folyószám.

4 Javaslat a hivatásos tiszthelyettesi állomány létrehozására. 1957. 05. 20. MNL HOP XIX-B-10 1957. év 23. sz. doboz VII/1. tárgykör, 49. folyószám. 
Mindezek miatt a szervezet életéból, múködéséból/múködtetéséból hiányzott az a tartóoszlop, amely a tisztek távollétében a rendet biztosította volna, megoldva az apró napi kérdéseket. A sorállományból a legtehetségesebbeket az alapkiképzést követóen tiszthelyettes-iskolára küldték Fótra (Zrínyi Miklós Tiszthelyettes Iskola). Ennek elvégzését követốen általában szakaszvezetônek avatva kerültek be a határôrségi vérkeringésbe, tiszthelyettesi munkakörökbe (ellentmondás, hogy a szakaszvezetói rendfokozat tisztesi rendfokozat, de viselói tiszthelyettesi feladatokat láttak el). Ez a felkészített katona viszont csak jó két évet dolgozott, majd leszerelt és visszatért a civil életbe. Nem válhatott olyan meghatározó személlyé, mint egy 10-15 évet szolgált hivatásos tiszthelyettes. Az iskolán 1956. október 19-én avattak 408 fó végzốs hallgatót, majd szabadságra küldték óket. Így 23-át követően (talán szerencséjükre) a határőrség nem tudott egyból az iskola állományához fordulni, bár elméletileg a tanintézeteket és kiképzó alegységeket mindig rendkívüli tartaléknak tekintették. A három századba szervezett tanintézet 1956. januárban 444 fó hallgatóval, 39 fó tiszttel, 12 fő továbbszolgáló tiszthelyettessel, 72 fő sor tiszthelyettessel, 22 fő sor határốrrel és12 fó polgári alkalmazottal múködött. Az intézmény viszonylag komoly fegyverzettel rendelkezett: $52 \mathrm{db}$ pisztoly, $65 \mathrm{db}$ géppisztoly, $472 \mathrm{db}$ puska, $36 \mathrm{db}$ távcsöves puska, 36 db golyószóró, 12 db géppuska, 1167 db kézigránát, négy db aknavetố, négy $\mathrm{db}$ tehergépkocsi, egy db személygépkocsi állt rendelkezésre.

A hivatásos tiszthelyettesek hiányából jelentkezó hátrányt próbálták feloldani, amennyire lehetett (persze nem lehetett), a "továbbszolgáló” állománykategória létesítésével. A leszerelő sorkatonák közül toboroztak kétszer négy éves időszakra bentmaradókat, továbbszolgáló ốrmester vagy szakaszvezetô rendfokozattal. Velük töltötték fel alapvetôen a biztosító/kiszolgáló munkaköröket, mint például raktáros, élelmezési tiszthelyettes, ôrs szolgálatvezetố stb. Sok esetben olyanok vállaltak további szolgálatot, akik nem rendelkeztek megbízható polgári foglalkozással, alacsony volt az iskolai végzettségük, életvitelükben gyakran megbízhatatlanok voltak. A juttatások gyenge színvonala, valamint fegyelmi okok sokszor vezettek leszereléshez.

A sorállomány nagyobbik része törekedett a szolgálat becsületes ellátására, és ez nagyfokú fizikai, lelki leterheltséggel járt. A mostoha elhelyezési viszonyok tưrése nem volt egyszerú.

Egy 1956. szeptember 4-én irattárba került értekezleti anyag annak ellenére is súlyos problémákat sorol fel, hogy elméletileg a határórség objektumaira a korábbi években jelentôs összegeket költöttek:

- 10 ággyal kevesebb van az ôrsön, mint a létszám, „ágyrajárók” a harcosok;

- nincs villany az örsön, annak minden következményével;

- nincs rádió;

- télen nem lehet fürdeni (Erzsébetpuszta);

- a szabadnapokat nem adják ki;

- a békekölcsön kötvényt nem kapták meg, hiába fizették be a katonák;

- a tornacipóket az elöljárói ellenôrzés során ôrsról oorsre vitték.

A határőrségnél tartott tavaszi és ôszi ellenőrzố szemlék, ebben az évben éppen október elején, az állomány kiképzettségének fokát gyakran a megfeleló szint alattinak értékelték. Különösen harcászati vonatkozásban, lövészeteken és a sorozatlövő fegyverek kezelésében jelentkezett lényeges elmaradás. 
1956. 01. 18-ai dátummal az országos értekezlet anyaga értékeli a határőrség '55. évi helyzetét. ${ }^{5}$ A 2. kerületnél a szemlén egy ôrs „kiváló”, egy ốrs , jó” , 12 ơrs megfelelő, 12 ốrs „nem megfelelö” (lényegében az ơrsök fele) lett. Ebben az évben mindhárom zászlóaljparancsnokot leváltották, éppen akkor, amikor az osztrák államszerzôdés életbe lépett. „Nem megfelelő” lett a kerület összesített lövészeti eredménye. 1954-ben 1604 fót, 1955-ben 1475 fót fenyítettek meg. Mindez egy nyugati-déli viszonylatú kiemelt köteléknél. A 3. kerület egyik zászlóaljánál, a géppisztoly 1-es lőgyakorlatnál, egyetlen ember sem ért el "megfeleló” eredményt, holott az 1-es szám egyszerú lógyakorlatra utal, a számok növekedésével emelkedett a lövészet nehézségi foka. Lényegében, saját beismerés szerint is, harcászati feladatokra nem készítették fel elfogadható szinten az állományt. Az alacsony kiképzési helyzet okairól terjedelmes tanulmányt lehetne összeállítani a meglévố értékelésekból; az okok a katonapedagógiai szempontoktól szervezési-biztosítási problémákig nyúlnak. Én a legsúlyosabb hibának azt látom, hogy a határốrség nem rendelkezett állandó kiképzó kerettel, annak tagjait ideiglenesen a felkészítés idejére más beosztásokból vonták össze három hónapra. A vezetók a leggyengébb felkészültségú, problémás beosztottaikat vették ki a napi munkából. Azokat, akiket a leginkább nélkülözni tudtak, és ez rányomta bélyegét az egész tevékenységre.

A „hazaárulás”, a „külföldre szökés” mindenkor a határốrség réme volt. Megakadályozására a szervezetnek valójában igen csekély eszközei voltak. 1955-ig, az osztrák államszerződés megkötéséig és a szovjet csapatok ehhez kapcsolódó, Ausztriából történt kivonásáig még nyugaton is létezett ennek egy viszonylagos ellensúlya. A szomszédunknál található szovjet megszállási zóna az államhatár túlsó oldalán húzódott, és akit a szovjet hatóságok valamelyik ellenőrző pontjukon feltartóztattak, azt visszaadták. Ez a lehetôség 1956-ra megszúnt.

A korábbi hazaárulási statisztikát nézve1954-ben hét fő,1955-ben 21 fő,1956-ban április 25-ig hat fó szerepel a határórségi adatokban. Az 1956. január és szeptember közepe közötti idôszakban 12 úgynevezett hazaárulási eset (külföldre szökés) anyaga található a levéltárban. Ezek közül három tiszt és kilenc fő sorkatona. A külföldre szökésre számtalan esetben osztrák csendőrök, vámórök, vasutasok, de magánszemélyek is úgynevezett „átbeszélés" közben próbálták rávenni a katonákat. Amikor a Bucsu ớrsról eltúnt egy határőr februárban, az „Amerika Hangja Európából” bemondta, az osztrák kormány pedig hivatalosan közölte, „hogy szombatról vasárnapra virradóra egy újabb magyar határór menekült Ausztriába és kért politikai menedéket. A magyar határớr, akinek nevét nem közölték, egyenruhában és teljes felszereléssel szökött át a határon."

A háttérben meghúzódhattak súlyosabb problémák, amelyekre egy-egy fennmaradt levélból következtethetünk. Az országos parancsnok 1956. 07. 11-én írásban reagál egy fegyveres sérülés kivizsgálására, amelyet a győri kerület terjesztett fel. Ebben felveti, hogy nincs megfelelő rend a helyszínen. „Zengó Lajos volt áv. hőr. a fegyverraktárt feltörve fegyvereket tudott kivinni az ốr szeme láttára, s utána több társával hazaárulást követett el Ausztriába." ${ }^{\prime \prime}$ A megnevezett határór a szállítóalegységnél

5 Jelentések a kiképzés állapotáról. MNL HOP XIX-B-10 6. sz. doboz 1956. év I/4. tárgykör, 50. folyószám.

6 Országos parancsnoki levél. MNL HOP XIX-B-10 10. sz. doboz 1956. év III/3-4. tárgykör, 117. folyószám. 
teljesített szolgálatot, cselekményük az összeesküvés és zendülés tényállását mindenképpen kimerítette. Ugyanakkor nyilvánvalóan felveti a kérdést, valamint mások felelősségét, miként juthattak ki a mélységból az államhatáron át külföldre?

A kivizsgálások anyagaiból esetenként megállapítható, nem mindig van a kiszökések hátterében politikai jellegú indíték. A mostoha körülmények és a rendkívüli leterhelés, a járandóságok rendszeres, folyamatos elmaradása is vezethetett ilyen esetekhez. Az egyik alkalommal megállapították, a kiszökött katona februárban egy, márciusban kettó, áprilisban egy napot volt összesen nappali szolgálatban, és már az ötödik vasárnapra osztották be. ${ }^{7}$

A határórségnél évról-évre nagy számban veszítették el az életüket sor határórök valamilyen szolgálati vagy egyéb körülmény folytán. A „Névjegyzék, akik 1956-ban meghaltak" címet viselő kimutatás nem tartalmazza az októberi események áldozatait, e szerint:

- öngyilkosság miatt életét veszette 3 fö;

- gépkocsi balesetben elhunyt 1 fö;

- gondatlanságból agyonlótte magát 1 fö;

- a jeges árvízi mentés közben meghalt 1 fő (ő tiszthelyettes volt, nem sorkatona);

- fürdés közben vízbe fulladt 3 fő;

- részegen lováról leesett, meghalt egy hadnagy órsparancsnok.

Az elózó listán tíz név található július elsejei záró dátummal. Így nem szerepelhet rajta egy késóbbi baleset, ahol a határôrt szolgálatban véletlenül lelótték október 6-án a szombathelyi kerületnél, amikor fegyverrel jelző lövést adtak le.

\section{A sorállomány és az októberi események}

A határôrség sorállománya közel háromszáz különböző alegységnél, szervezetnél, széttagolva teljesített szolgálatot. Ennek megfelelóen az események a legkülönbözóbb eltérésekkel érintették óket. Más volt a helyzete a nyugati államhatáron, órsön szolgálóknak, a román határon lévóknek, vagy akiket nagy hirtelen az órsökról összevonva, ideiglenes századokba szervezve október 24-25-én felhoztak Budapestre a fegyveres felkelés elleni fellépésre.

A harcokban kilenc fô veszítette el az életét és 27 fó sebesült meg. ${ }^{8}$ Rendelkezünk a sebesültek határôr kerületenkénti megoszlásával ebben az anyagban. Ezek szerint: 1. kerület négy fő sebesült, 6. kerület 12 fő, 7. kerület egy fó, 8 . kerület három fö, 9. kerület egy fó, híradózászlóalj hat fő. A sebesültek 500-1000Ft gyorssegélyben részesültek a következô év elején, valamint különböző anyagi juttatásokban, mint például polgári öltözet. A késóbbiekben a sérülésük súlyosságának megfelelóen rokkantsági szintet állapítottak meg esetükben, egyesek kormánykitüntetést kaptak.

7 Kivizsgáló jelentés. MNL HOP XIX-B-10 9. sz. doboz 1956. év III./1. tárgykör, 49. folyószám.

8 „Kimutatás az 1956. évi októberi ellenforradalom ellen fegyveres harcokban hósi halált halt és megsebesült elvtársakról" MNL HOP XIX-B-10 10. sz. doboz 1956. év III/3-4. tárgykör, 144. folyószám. 
A legnagyobb veszteségek a pécsi 6. számú kerületet érték (12 sebesült és két halott sorkatona, a tiszteket nem számolva). Az ô esetükben október 25-én, a Parlament közelében a „Fehér Házat” biztosító belső karhatalmi őrség tévedésból túzharcot kezdeményezett a pécsi század megerôsítésül érkezó gépkocsioszlopával. A sorkatonák mellett két tisztet is agyonlőttek, egy tiszt a kórházban halt bele a sérülésébe.

A híradózászlóalj a másik kötelék, amelyik több fót elveszített (egy halott, 6 sebesült). Ennek magyarázata, hogy az alakulat Budapest mellett, Adyligeten állomásozott, és a kezdetektól fogva különbözó biztosítási feladatokra igénybe lett véve az állomány.

A kilenc sorkatona adatai, akik életüket veszítették az események során, részben szerepelnek a határőrség egy késóbbi kiadványában. ${ }^{9}$ Katonai szokás szerint családjuk állami támogatásban részesült, óket posztumusz elóléptették, kitüntették.

A határőrség nem rendelkezett olyan alegységekkel, amelyeket harcászati feladatok végrehajtására szerveztek. Október 24-én reggel mindenütt riadót rendeltek el, és áttértek járórcsoportok alkalmazására, megszervezték az objektumok védelmét, csoportokat rendeltek ki közigazgatási és rendôri épületek biztosítására. Több határór kerület (Balassagyarmat, Győrr, Pécs, Kiskunhalas, Orosháza) az ôrsökról bevont katonákból századokat állított fel, és azokat felrendelték Budapestre. Ezek az ideiglenesen összeállított kötelékek nem voltak alkalmasak harcászati tevékenység folytatására, hiányzott a felkészítés, a begyakorlottság, de leginkább a lakott területen folytatott harchoz szükséges harcjármú és tüzérségi eszköz. Egyetlen úttorlasz, barikád fedezékéból vagy épületek ablakából nyitott túz megállította a tehergépkocsin szállított szakaszokat, lehetetlen helyzetbe hozva óket. Mutatja ezt például Bózváry Imre határớr esete az orosházi kerülettól felvezényelt századból. A határốrt a Kilián laktanyánál végzett felderítés során lótték agyon egy épület ablakából október 24-én. Két társa súlyosan megsebesült. A Korvin kórházban, majd a Kerepesi temetóben temették el. A határór híradózászlóalj teherautókon a rádió épületéhez küldött erôit a Nagykörút-Baross utca sarkán egy egyszerú barikád mögül érte támadás. Megfelelő eszközök hiányában alig tudtak kimenekülni, visszafordulni a túzharc folyamán. Egy határőr, Egervári László az életét veszítette, és négy-öt fő megsebesült. ${ }^{10}$

Az épületek biztosításában (BM, HM, Lakihegyi Rádióadó, Határórség Országos Parancsnokság, egyéb saját objektumok, vezetói lakások és családok órizete), járórszolgálatban ugyanakkor szakszerúen tevékenykedtek. A fegyveres felkelókkel szemben kezdeményezően, támadólag lényegében nem léptek fel.

Október 24-étól általában megszúnt a „zöldhatár" oórizete. A tiszti állomány az ớrsökön maga sem tudta mit tegyen, a sorállomány sok helyen irányítás nélkül maradt. A napi katonai életritmus megszúnt. A határórök kijártak a településekre, átjártak Ausztriába, hazamentek, a szabadságon lévók nem tértek vissza, barátkozás

9 Szilvási Ferenc: Határór hősök nyomában. Budapest, BM Határôrség Politikai Csoportfőnökség kiadványa, 1987. Második, bóvített kiadás.

10 Berki Imre: A Határórség Közvetlen Híradó Zászlóalja az 1956-os forradalom és szabadságharc sodrásában. Rendvédelem-történeti füzetek (Acta Historiae Praesidii Ordinis), XXVI. évf. (2016), 51. szám. 16. o. 
kezdődött a megalakuló helyi felkelő szervekkel. Október 30. után megkezdődött a katonatanácsok múködése, ${ }^{11}$ amely teljesen felborította a hivatásos és sorállomány kapcsolatát. Egyes laktanyákat elhagytak, a helyi lakosság részvételével az anyagokat, eszközöket, fegyvereket is széthordták. ${ }^{12}$

Több kerületnél (Nyírbátor, Balassagyarmat) a parancsnokság által kiadott igazolással leszerelték a legidósebb korosztályt.

\section{November 4. után}

November 4-én és 5-én a szovjet csapatok felzárkóztak az államhatárokra, és behatoltak a kerületparancsnokságokra, az ország belsejében lévő laktanyákba. Fegyveres összeütközésre sehol sem került sor. Az országos parancsnok, Szalva János ezredes még az események kezdetén megtiltott minden ellenállást. A sorállományból egyesek külföldre menekültek, fóleg Ausztriába, sokan az ország mélységébe, többnyire a lakóhelyükre szöktek. Elterjedt az a rémhír, hogy a katonákat Szibériába deportálják. Más alegységek állománya teljes egészében a helyén maradt, az események lefolyása jelenós mértékben a parancsnokló tisztek magatartásától függött. A kiskunhalasi kerületparancsnokság katonáit negyedikéig egyben tartották a tisztek saját órséggel. Negyedikén este, szovjet utasításra, bevonták a fegyveres órséget, bár a magyar tisztek felvetették, hogy a sorkatonák az éjszaka elszöknek. Menjenek, mondta a szovjet parancsnok, úgy is vissza kell jönniük.

1956 novemberétól újra kellett szervezni a határórizetet és a határórséget. A feladat egyik súlyponti kérdésének a sorállomány alkalmazása bizonyult. Az akkor múködő járôr rendszerú szolgálatellátás nem nélkülözhette az élőerôt, a katonát. November 10-15. között leszerelték a hároméves szolgálatot ellátott legidősebb korosztályt. Februárban leszerelték az 54-es korosztályt két év három hónap katonai szolgálat után. Jelentôs létszámhiány keletkezett.

A fegyveres erók minisztere (teljes megnevezéssel „a fegyveres erók és közbiztonsági ügyek minisztere" , dr. Münnich Ferenc) felhívást tett közzé, hogy a katonák és a rendészeti szervek munkatársai jelentkezzenek szolgálati helyeiken december 10-ig. A felhívást a Kossuth Rádióban ismételten beolvasták. Ennek ellenére néhány katona csak augusztusban bukkant fel. A kerületparancsnokságok a távollévóknek több alkalommal küldtek az ismert lakcímükre táviratot berendelő szöveggel. A következô hónapokban a hiányzókat a rendőrség állította elö.

Az országos parancsnok a 036/Szerv./1957. sz. rendeletében szabályozta, mi legyen azokkal, akik december 10. után késve térnek vissza a szolgálati helyükre. Ezek az úgynevezett „visszatartottak”, mert az országos szabályzás szerint nem szerelték le óket a szolgálati idejük leteltével, hanem február 10-tól indított számvetéssel a távol töltött napokat pluszban le kellett szolgálniuk. Láthatólag a határórség „katonásan”

11 Fórizs Sándor: Katonatanácsok a határórségnél 1956-ban. Hadtudomány, XXIX. évf. (2019), 1-2. szám, 96-111. o.

12 A katonatanácsok honvédségi szervezetekre gyakorolt hatását mutatja be könyvében Berki Mihály: Hadsereg vezetés nélkül. Budapest, Magyar Média Kiadó, 1989. 
a legszigorúbb, és meggyózódésem szerint, a legrosszabb megoldást választotta. Ahelyett, hogy a leggyorsabban megszabadult volna az érintettektól, azok a szervezetben maradtak, de nem tudtak semmit sem kezdeni velük, csak az amúgy is jelentốs feszültséget fokozták. Sem az államhatárra, sem az ország mélységébe, járórszolgálatba nem lehetett vezényelni óket, egyáltalán nem volt ajánlatos fegyvert adni a kezükbe. Kicsinyesen még 20-50, akárhány napot bent tartották az érintetteket. A pécsi kerületnél 24 fő 4-50 nappal tartozott közéjük. Csak őrölték a tiszti állomány idegeit, és lázítottak a fiatalabb korosztályok körében. Az 1. határơr kerület Győr felterjesztése szerint ${ }^{13}$ még február 28-án is 135 fó hiányzott. Annyiban jobb volt a helyzet, hogy a távollévók egy részéról tudták, és a névjegyzéken jelölték, az illetô bejelentkezett a lakóhelyéhez legközelebbi határór objektumba, ahonnan már nem is engedték el, azonnal munkába állították.

A határőrök visszatartásáról szóló másik okmány ${ }^{14}$ szerint, ezen katonák száma a 2. kerületnél, Csornánál 70 fó volt az 1954. évi bevonulásból. Óket Sopronban a zászlóalj tartalék századához vonták össze (ahol persze semmit sem tudtak kezdeni a társasággal). Amikor közölték velük, hogy késóbb szerelnek le, „forradalmi katonai tanácsot" választottak, amelynek tagjait a parancsnokság fogdába helyezte.

A megszüntetett belsó karhatalom sorállományát betagolták a határôrség szervezetébe. Mivel 1956. novemberben nem lehetett végrehajtani a következő bevonulást, a határơrség megüresedett sorállományú helyeit a honvédségtól kellett feltölteni. 1957 júliusáig 8500 fố sorkatonát csoportosítottak át a határôrséghez, ${ }^{15}$ és a következô bevonulást az ô szolgálati idejük alatt áprilisban szervezték meg. A honvédek ilyen nagy létszámú átvétele nem zajlott zavartalanul. Egyes kerületek (például Balassagyarmat, Miskolc) állományának 80-85\%-át az újonnan érkezettek tették ki, és még májusban is Miskolcon 140 fó honvéd átképzése folyt. Keleten szinte nem maradt eredetileg a határốrséghez bevonult személy, mindenkit áthelyeztek nyugatra. Idôközben a nyugati és déli államhatáron végigsöpró bizalmatlansági válság miatt az ott lévő határőrök közül sokat átvezényeltek az úgynevezett „baráti viszonylatokba”, illetve az osztrák államhatárt keletról és délról erósítették meg. Február 26-án összesen 9955 fő sorkatona volt a határórségnél, az állománytábla szerint hiányzott 2630 fó, holott ekkor már 1957. 02. 25-ig 6590 fót átvettek a honvédségtól. ${ }^{16}$

Az átvettek részére egy gyors, általában tíz-tizenöt napos határórizeti felkészítést szerveztek, majd az őrsökre és kiszolgáló alegységekhez helyezték óket. Komolyabb megbízhatósági ellenôrzést az érintettek elóéletére és az októberi tevékenységére vonatkozóan nem lehetett tartani, tekintettel a zavaros idókre és az elpusztult

13 „Névjegyzék, azon harcosokról, akik sem felhívásra, sem pedig behívó parancsra nem vonultak be." 1957. 02. 28. MNL HOP XIX-B-10 24. sz. doboz 1957. év VII/2-5. tárgykör, 91. folyószám.

14 Jelentés a határőrök visszatartásáról. 1957. 02. 06. MNL HOP XIX-B-10 24. sz. doboz 1957. év VII/2-5. tárgykör, 90. folyószám.

15 Legalább is ennyi nevet tartalmaz egy rendelkezésre álló levéltári lista, amelyen sem dátum, sem aláírás nem szerepel, és láthatólag egy nagyobb anyag része lehetett valamikor. Jelentés a honvéd vezérkarnak. 1957. 07. 08. MNL HOP XIX-B-10 24. sz. doboz 1957. év VII/2-5. tárgykör, 94. folyószám.

16 Kimutatás a határốrség létszámáról. 1957 02. 26. MNL HOP XIX-B-10 24. sz. doboz 1957. év VII/2-5. tárgykör, 92. folyószám. 
dokumentációkra. Ennek következtében olyanok is az államhatárra kerültek, akik részt vettek az októberi megmozdulásokban, közvetlen hozzátartozóik külföldre menekültek stb. Közülük nem kevesen szöktek át a túloldalra. A határórségi jelentések olyan gyakran írták, hogy a szökevény eredetileg honvéd sorkatona volt, hogy maga a miniszter kérte ennek leállítását.

Nem volt zavartalan a kétféle állomány „összeillesztése” sem. A régi határôrök „ellenforradalmárnak" gúnyolták az újakat, azok pedig gyakran nem kívántak úgymond az „ÁVH-nál” szolgálni. Az első időszakban járốrcsoportok, öt-hat fó tevékenykedett szolgálatban egy idősebb határôr vezetésével. Ez megkönnyítette a beosztottak ellenôrzését és irányítását, illetve az esetenkénti nagy létszámú 30-40 fős határsértố csoportok elleni fellépést.

\section{Az 1957-es évben elhunyt határörök}

Ez évben legkevesebb 23 határór hunyt el, közülük három tiszt. ${ }^{17}$

Statisztika szerint az alábbi események szerepelnek a kimutatásban:

- baleset szolgálaton kívül négy fő;

- öngyilkosság hét fó;

- szolgálatban megölték három fő;

- egy név valamiért nincs indokolva;

- egy rosszul lett szabadságon és meghalt, nem világos miért került a neve a listára;

- szolgálatban fürdött, megfulladt egy fó;

- szolgálatban gondatlanságból bekövetkezett baleset négy fő;

- lövészeten halt meg egy fó;

- téves bejegyzés egy fó.

A halottak között található Módos József határốr, akit 1957. 01. 17-én a győri kerület, Rajka ôrsén elfogott határsértók megtámadtak és megöltek, leütötték a saját fegyverével.

Vajda János határór járőrparancsnokot a szombathelyi kerület, Felső́csatár ôrsén 1957. 06. 15-én szolgálat közben agyonlőtte a járôrtársa, és fegyverével együtt átszökött Ausztriába. Kiliti Dániel tizedes egy elfogás közben kialakult lövöldözés során veszítette életét 1957. 01. 12-én a csornai kerület, Sopronkövesd őrsén.

A családokat természetesen mélyen érintették az események. Herczeg Imre határőrt 1957. 06. 30-án őrszolgálatban agyonlőtte egyik társa, a kivizsgálás szerint gondatlanságból. A rendszerváltást követóen 1992-ben vizsgálták újra az esetet a rokonok kérelmére.

\section{Sérülések az aknamezón/múszaki záron}

Az 1956. szeptemberre megszüntetett múszaki zárat és aknamezốt 1957 májusától újra telepítették. A nagy sietve végrehajtott munka alapvetően szintén a honvédségi és határôrségi sorállományt terhelte. Nem csak a telepítés, a további folyamatos

17 „Névjegyzék 1957. évben meghaltakról." MNL HOP XIX-B-10 14. sz. doboz 1957. év III/2-4. tárgykör, 365. folyószám. 
kiszolgálás is rendkívül veszélyes tevékenységnek bizonyult, nagy figyelmet igényelt. Egy másik dokumentum ${ }^{18}$ részadatokat tartalmaz az aknasérülésekkel kapcsolatban, amelyek a telepítés vagy a napi tevékenység közben következtek be. A 11 név között egy tiszt, egy tiszthelyettes és kilenc sorkatona szerepel.

A jegyzéket természetesen nem lehet teljesnek tekinteni, mert ugyanebben az 1957. évi 14. számú iratgyújtő dobozban, más nyilvántartási számú okmányokban további egy tiszt és három sorkatona sérüléséról írnak.

\section{Külföldre szökések, hazaárulások}

A hivatásos állomány számára a határốr szolgálat réme a külföldre szökés és a halálos fegyveres baleset volt. Lényegében járôrszolgálatban vagy esetleg egy olyan ôrsön, amelyik néhány száz méterre található az államhatártól, fizikailag nem jelentett nagyobb nehézséget megszökni. Egy, a bekövetkezett hazaárulásokról készített jelentés, aláírta a határórség törzsparancsnoka (törzsfónöke), 1956. október 23-tól 1957. szeptember 1-ig a külföldre szökött határórök számát 505 fóben adja meg, közülük 130 fő a honvédségtól átvett katona. Az ország belseje felé irányuló szökések, engedély nélküli távolmaradások ebben az adatban nem szerepelnek. Mindenesetre a hazaárulások száma folyamatosan csökkent, bár még 1958 elsó negyedévéból is öt fóról tudunk.

Az amnesztiarendelet alapján március 31-ig három tiszt, hét tiszthelyettes, 116 sor határôr tért vissza.

A külföldre szökések veszélyes változatát képviselték azok az esetek, amikor a szökni szándékozók társaikra fegyverrel támadtak. „Olyan eset is történt, mint Pfeil Henrik volt hôr. esetében, aki 1957. június 15-én járórszolgálat közben agyonlótte járôrparancsnokát, és így követte el a hazaárulást. Győrvári János volt hôr. a Gyôr-i kerület Pusztasomorja-i ôrsén lefegyverezte járórparancsnokát, majd hazaárulást követett el. Lázár László volt tiz. és Borbás József volt hőr. járőrparancsnokok járőrszolgálat közben összetalálkoztak, elhagyták járórtársaikat, majd tüzet nyitottak rájuk, és ennek fedezete mellett szöktek Ausztriába."19

„A legkirívóbb eset a Csorna-i ker. Hermes-i órsén történt, ahol a személyi állomány nagy része szervezkedett hazaárulás elkövetésére, amit úgy akartak végrehajtani, hogy az ôrs parancsnokát meggyilkolják." 20

„Igen magas a fegyvertól történt sérülések száma, melynek következtében 30 súlyos sérülés és 3 halálos sérülés történt." 21

18 „1957. évben a határórségnél történt rendkívüli események, búncselekmények, fegyelmi vétségek." MNL HOP XIX-B-10 14. sz. doboz 1957. év III/2-4. tárgykör, 358. folyószám.

19 „Jelentés. Hazaárulásról kimutatás." 1957. 09. 17. MNL HOP XIX-B-10 14. sz. doboz 1957. év III/2-4. tárgykör, 363. folyószám.

20 „Jelentés a határórség helyzetéról” 1957. 07. 13. MNL HOP XIX-B-10 17. sz. doboz 1957. év IV/10. tárgykör, 151. folyószám.

21 Uo. 
„Az ellenséggel való összejátszás miatt elhárító szerveink 7 foót tartóztattak le és adtak át a hadbíróságnak, így például Földes Mihály hdgy-ot, akit a hadbíróság embercsempészés és rablás miatt 10 évre ítélt el." ${ }^{22}$

\section{A bevonuló sorállomány ellenórzése}

Az 1957. áprilisi, az 1956. október utáni elsô bevonulást különös körültekintéssel végezte a határórség. Ez volt az elsô igazi lehetôség, hogy a sorállományt a saját szempontjai szerint kiválogassa, fokozott biztonsági ellenórzést végrehajtva. A felkészítés tizenegy különbözó bázison történt. A BM Határoórség Országos Parancsnokság Felderító Osztály III. alosztály a kerületek felderítő alosztályaival és a honvédséghez tartozó kiegészítő parancsnokságokkal együttmúködve „átrostálta” a bevonultatni tervezett és a már bent lévố állományt. Június 11-én készült jelentésük ${ }^{23}$ az alábbiakat tartalmazza.

Sok a bevonultatási probléma, a kiegészítő parancsnokságoknál a határórség 350-400 fốt kirostált, de végül mégis behívtak 89 olyan személyt, akik a határórségnek nem felelnek meg. Az újoncok közül 350-400 fó van, aki csak keleti és északi viszonylatban alkalmazható.

Komárom, Győr-Sopron megyék területéról az újoncok 70-80\%-a rendelkezik nyugati kapcsolattal. Nagy probléma a kiképzố tiszthelyettesek hiánya, az újoncok bántalmazása, a durva magatartás. Javasol 180 fốt a honvédséghez áthelyezni a kiképzés végeztével.

Az ugyanitt található másik jelentés ${ }^{24}$ szerint sok a nyugati kapcsolattal rendelkezô személy, olyan, aki maga vagy rokona októberben kifogásolható tevékenységet folytatott, nemzetốr volt, búntetve volt, novemberben disszidált majd februárban hazatért, lopásért volt büntetve, szándékos emberölésért eljárás folyik ellene. Összesen 178 személyt név szerint kifogásol a jelentô. A határôrséghez szánt sorkatonák előszúrésében mindig jelentôss szerep jutott az állambiztonsági szolgálatok illetékes szervezeteinek. ${ }^{25}$

\section{A járórszolgálat ellátása}

Az államhatár lezárásának kulcskérdése a járôrszolgálat ellátása lett. Nem bizonyult elegendônek feltölteni az üres helyeket a honvédségtól átvezényelt sorkatonákkal, el kellett érni, hogy tegyenek is valamit szolgálatban. Különösen vonatkozik ez a határőr járő́rszolgálatra, ahol a katonák szolgálati idejük nagyobbik részét felsóbb

22 Uo.

23 „Tárgy: Tájékoztató és hangulati jelentés a kiképzó egységekról” 1957. 06. 11. MNL HOP XIX-B-10 14. sz. doboz 1957. év III/2-4. tárgykör, 352. folyószám.

24 „Tárgy: A bevonultatott újoncok között lévő súlyosabb terhelő adatokkal rendelkező személyekról." MNL HOP XIX-B-10 14. sz. doboz 1957. év III/2-4. tárgykör, 352. folyószám.

25 Az ellenórzéssel kapcsolatban lásd még Deák József publikációját: Az állambiztonsági propaganda, annak kialakulása és fejlődése - nemzetbiztonság és civil kapcsolatok.

Társadalom és honvédelem, 17. évf. (2013), 3-4. szám, 408-417. o. 
ellenórzés nélkül önállóan látták el. Az október 23-november 10 közötti idóben lényegében nem folyt határórizet. Egyes ôrsök állománya megszavazta, hogy éjszaka nem járnak szolgálatba, személyeket nem igazoltatnak, megszúnt a laktanya belsó rendje, nem volt szolgálat szervezés, parancskihirdetés, stb. A határórök egy része átjárt külföldre, üzletelt a helyi lakosokkal és a külföldiekkel. A tisztek közül azokat, akiket nem kedveltek, több helyen fegyverrel, erószakkal elkergették. A novemberben beindult menekülthullám vámszedói is gyakran a sorkatonák közül kerültek ki, nem csak egyszerúen elnézték a tiltott határátlépést, sarcolták az abban résztvevóket. Pénzért, ruháért, kisebb ékszerekért engedték el a menekülóket. Gyorsan kialakultak az embercsempész hálózatok, amelyekben a helyi lakosoknak, sorkatonáknak, de a tiszteknek is megvolt a szerepe és jelentôs bevétele.

A gyoóri kerülethez tartozó Erzsébetpuszta órs helyzetéról a kerület parancsnoka külön jelenésben számolt be. „Az ellenforradalom idején az ôrs személyi állományának egy részét, beleértve a tiszteket is az ellenforradalmárok elvitték a Bécs-i közúti átkelőhelyhez és ott fogságban tartották óket." ${ }^{26}$ Az oorsöt 1956. november 8-án szervezték újjá. „16 fő követett el az ôrsról hazaárulást, 11 határôr foglalkozott embercsempészettel, de a volt órspk. Major Béla hdgy. is." ${ }^{27}$ Áldatlan elhelyezési körülmények uralkodnak a laktanyában. Nincs víz, villany, két, vályogos, fútetlen parasztház, nincsenek raktárak, fegyverszoba. Nincs tiszti lakás. A tisztek a katonákkal alszanak, a nyomsáv 11 m-re van az objektumtól. Mosdás, tisztálkodás lavórban.

\section{A szolgálati rend helyreállitása}

November negyedikét követóen a létszámviszonyok rendezésén túl a legfontosabb feladatának a határốrség vezetése a szolgálati fegyelem helyreállítását és ennek segítségével az osztrák államhatár lezárását tekintette. A cél érdekében két igen fontos eszközt alkalmaztak. Az egyik a nyugati órsök hivatásos állományának szinte teljes lecserélése volt. A következő év közepétól már hadnagyok és fóhadnagyok kezébe adták a határórizet elsô vonalának irányítását. A másik eszköz a határớrség „saját” katonai ügyészsége, amely 1957 végéig valóban a határórség szervezetében, annak állománytábláján belül tevékenykedett. A határórség tagjaival szemben lefolytatott ügyészségi és katonai bírósági eljárásokat külön publikáció dolgozza fel. ${ }^{28} \mathrm{Az}$ elóbbiek miatt nem kívánok részletesen foglalkozni a kérdéskörrel. A levéltárban az 1957-es év anyagai közül két teljes doboz tartalmazza a kapcsolódó okmányokat, holott láthatóan rengeteg dokumentum hiányzik. A bírósági ítéletek közül említsünk meg néhányat:

- Örutasítás megszegése. Leittasodott a katona szolgálatban, 6 hónap, büntető zászlóalj. Visszatartás céljából nyilvános helyszíni tárgyalások az alegységeknél.

- Fegyver és lőszerrejtegetés búntette, önkényes eltávozás, 2 év börtön.

26 „Tárgy: Erzsébetpusztai oorsról összefoglaló jelentés.” 1957. 04. 12. MNL HOP XIX-B-10 15. sz. doboz 1957. év IV/1-6. tárgykör, 6. folyószám.

27 Uo.

28 Fórizs Sándor: Katonai ügyészségi és bírósági eljárások a határőrség tagjaival szemben 1956-57-ben. Katonai Jogi és Hadijogi Szemle, 2018/2. szám, 53-87. o. 
- Órutasítás megszegése. Járốrtársa szolgálatban kiszökött, ô volt a járốrparancsnok, 10 hónap.

- Önkényes eltávozás. 1956. október 20-án nyolc nap szabadságra távozott ahonnan alakulatához nem tért vissza. 1957. 03. 06-án szülei lakásáról állította eló a rendốrség, 7 hónap.

- Órszolgálati búntett. Kétfốs járớr leittasodott, lövöldözött, 8 és 10 hónap.

- Gondatlanságból elkövetett emberölés. Nyúlra lőve agyonloótte a társát, 1 év.

- Örutasítás megszegése. Szolgálati helyét elhagyta és bement egy kocsmába, 1 év.

- Függelemsértés. Feljebbvalóját tettleg bántalmazta, 6 hónap.

- Függelemsértés. Elöljáró tettleges bántalmazása, 1 év.

- Csoportos tiltott határátlépésben való segítségnyújtás búntette, vesztegetés. Személyeket segítettek át az államhatáron. A hét sorkatona büntetése 8 hónap, 1 év, 8 hónap, 1 év, 1 év 6 hónap, 1 év 6 hónap, 6 hónap.

- Órszolgálati bûntett. A két határốr szolgálatban szórakozásból lövöldözött, 8 illetve 4 hónap.

- Jelentéstétel elmulasztása. Az észlelt határsértő mozgást nem jelentette, 8 hónap.

- "Népidemokratikus államrend elleni izgatás búntette". 3 év 6 hónap.

- "Népidemokratikus államrend elleni izgatás búntette". ${ }^{30} 2$ év.

Nem kívánom folytatni a felsorolást. Az előzőekból is látszik, milyen széleskörú jogi eszközök álltak a határőrség rendelkezésére a sorkatonákkal szemben. A levéltárban az 1957. év 12. és 13. számú dobozaiban (de máshol is vannak elszórva hasonló okmányok) található ügyészségi határozat összesen 71 darab, vádirat 31 darab 48 fóvel szemben.

Katonai bírósági ítélet 96 lelhetó fel 147 személlyel szemben. További 21 ítélet a Népköztársaság Legfelsóbb Bíróságához kapcsolódik. A bírósági dokumentumokban 43 különbözó búncselekménytípus szerepel. ${ }^{31}$

A „Népidemokratikus államrend elleni izgatás búntette”-inek elófordulásai is azt igazolják, hogy a nyugati fellazító propaganda több tekintetben eredményes volt. $^{32}$

Nagycenk órsön hét sorkatona dolgozott össze embercsempészekkel.

14 határőrt a Fertőrákos és Magyarfalva ơrsökról a katonai bíróság 6 hónaptól 2 év 2 hónapig terjedő börtönbüntetésre ítélt embercsempészetért. Nagykölked ôrsról 4 sorkatonát 1 évig terjedő börtönbüntetésre ítéltek. Egymást érik a sorkatonákkal szembeni eljárásokról szóló parancsok. ${ }^{33}$

29 MNL HOP XIX-B-10 1957. év 2. sz. doboz I-2. tárgykör, 2. folyószám. 1957. évi személyi állományra vonatkozó parancsok.

30 Uo.

31 A katonai büntetốjog kapcsolódó kérdéseit dolgozza fel publikációjában Hautzinger Zoltán: A katonai büntetójog rendszertana. Pécs, AndAnn, 2010. 1-109. o.

32 Deák József: The Psychological Struggle between East and West as Reflected in the Interior Rewiew up to the European Safety and Cooperation Conference (1953-1975). Prague Papers on the History of International Relations, Vol 11. Issue 1. Prague, Charles University, 2015. 112. o.

33 Parancsok 1957-ból. MNL HOP XIX- B-101957. év 1. sz. doboz I-1. tárgykör, 3. folyószám. 


\section{Összegzés}

A határórség 1956-1957-es történetében meghatározó állománykategória volt a sorállomány. Egyben a legkiszolgáltatottabb állománycsoport, amelynek a helyzetével kevesen törődtek, és érdekeik érvényesítésére lényegében nem rendelkeztek eszközökkel. A sorkatonai szolgálatnak állampolgári kötelezettségként tettek eleget, belesodródva esetenként életveszélyes helyzetekbe.

Munka és életkörülményeik gyakran rendkívül sivárak, megterhelók, egyeseknek, például az aknazár miatt, kimondottan életveszélyesek voltak.

Az általunk vizsgált idôszakban október 23. és november 4. között lényegében szétesett, vagy legalábbis megroppant az a tevékenység, amelyre bevonultatták óket, majd rövid idôn belül újból a legszigorúbb rezsim alá kerültek. Kormányváltások történtek, és eltéró ideológiai befolyások, követelmények érték óket. Nincs semmi csodálkozni való azon, hogy sokan nem igazodtak el az események között. Számukra nem adatott meg az a lehetôség, mint a tiszteknek, hogy a politikai folyamatok elutasításaképpen leszereljenek (a határôrségi hivatásos állomány 38\%-a lépett ki a szervezettól 1957 végéig).

A fegyveres harcok idején, szerencséjükre, a többség a távoli tanyasi, falusi ôrsökön lényegében kimaradt az események sodrából. A késóbbi heroizáló határôrségi emlékezettel szemben sem a helyben maradt, sem pedig a Budapestre felhozott erók nem folytattak aktív támadó tevékenységet a felkeléssel szemben, (erre egyébként nem is voltak alkalmasak). Múködésük többnyire objektumok biztosításában, védelmében merült ki.

November negyedikét követóen az új munkás-paraszt kormány fokozottan rászorult a határơrség tevékenységére, hiszen útját kellett állnia a többszázezres menekülési hullámnak. A cél érdekében minden eszközt bevetettek, újra telepítették az aknazárat, határövezetet állítottak fel, kivételes jogrend került bevezetésre, és ennek során megint a sorkatonaság játszotta a főszerepet a járőrszolgálatban, megerôsítve a honvédségtól átcsoportosított erókkel.

A határőrség szervezetén belül olyan mértékú lett a visszaesés a katonai fegyelem vonatkozásában, hogy az csak 1958 közepére érte el a korábbi szintet, amikorra leszereltek az események által érintett korosztályok, átadva helyüket a lényegesen gondosabban kiválogatott és felkészített újoncoknak.

\section{FELHASZNÁLT IRODALOM}

Az 1956. évi 27. tvr. az 1956. évi október hó 23. napját követóleg külföldre távozott személyek közkegyelemben részesítéséról (dec. 1.)

Berki Imre: Az adyligeti Határórezred története. PhD értekezés. ELTE, Budapest, 2015.

Berki Imre: A Határőrség Közvetlen Híradó Zászlóalja az 1956-os forradalom és szabadságharc sodrásában. Rendvédelem-történeti füzetek (Acta Historiae Praesidii Ordinis), XXVI. évf. (2016), 51. szám. https://doi.org/10.31627/RTF.XXXVI.2016.51N.15-24P

Berki Mihály: Hadsereg vezetés nélkül. Budapest, Magyar Média Kiadó, 1989.

Deák József: Az állambiztonsági propaganda, annak kialakulása és fejlődése - nemzetbiztonság és civil kapcsolatok. Társadalom és honvédelem, 17. évf. (2013), 3-4. szám, 408-417. o. 
Deák József: The Psychological Struggle between East and West as Reflected in the Interior Rewiew up to the European Safety and Cooperation Conference (1953-1975). Prague Papers on the History of International Relations. Vol 11. Issue 1. Prague, Charles University, 2015. 112. o.

Fórizs Sándor: Katonai ügyészségi és bírósági eljárások a határôrség tagjaival szemben 1956-57-ben. Katonai Jogi és Hadijogi Szemle, 2018/2. szám, 53-87. o.

Fórizs Sándor: Katonatanácsok a határốrségnél 1956-ban.

Hadtudomány, XXIX. évf. (2019), 1-2. szám, 96-111. o.

Hadtudományi Lexikon M-ZS. I-II. Budapest, Magyar Hadtudományi Társaság, 1995.

Hautzinger Zoltán : A katonai büntetójog rendszertana. Pécs, AndAnn, 2010. 1-109. o.

Szilvási Ferenc: Határốr hősök nyomában.

Budapest, BM Határốrség Politikai Csoportfónökség kiadványa, 1979.

Szilvási Ferenc: Határốr hôsök nyomában. Második bóvített kiadás.

Budapest, BM Határơrség Politikai Csoportfőnökség kiadványa, 1987. 